\title{
The Birth of Information Systems
}

\author{
Audra Lukaitis, Stas Lukaitis, and Bill Davey \\ RMIT University, Melbourne, Australia \\ \{Audra.Lukaitis, stas, Bill. Davey\}@rmit.edu.au
}

\begin{abstract}
This paper traces the history of the development of information systems degrees in one of the largest Australian universities. A synthesis of documents and transcripts of interviews with the participants shows that information systems grew from an amalgam of existing business courses. The shape of the degrees was initially forged by politics and personality, with a stable and robust curriculum in place after a number of years. This historical narrative shows that university curriculum reflected the significant impact of information technologies in business.
\end{abstract}

Keywords: information systems curriculum, information systems history, information systems.

\section{Introduction}

Australia has a long history, relatively, of computing. The CSIR Mk1 (CSIRAC Council for Scientific and Industrial Research Automatic Computer), built in the late 1940s was Australia's first internally-stored-program computer and is acknowledged to be the world's fourth [1]. People from this burgeoning area were recruited into universities at a very early stage. At the Royal Melbourne Institute of Technology (now RMIT University) Brian O'Donahue from the Commonwealth public service was recruited to head the Data Processing Group. People like Cliff Forrester, who had become engaged by computers after working on EDSAC (Electronic Delay Storage Automatic Calculator) in England as a result of his aeronautical jobs at Farnborough, drifted from some part time teaching at Caulfield Institute (one of the first Colleges to offer formal degrees in information systems) into a full time role at Royal Melbourne Institute of Technology (RMIT).

\subsection{RMIT University Beginnings}

RMIT is one of the largest universities in Australia. It offers undergraduate and postgraduate degrees in a number of computer-related areas, principally computer science and information systems. The first is quite old in Australian terms. The University opened for business on 7 June, 1887, as the Working Men's College with an initial enrolment of 600 students. By 1988 The College offered classes in technical, business and arts with an emphasis on applied skills relevant to trades including architectural and mechanical drawing, theoretical and applied mechanics, plumbing, carpentry and painting. Studies in arithmetic, algebra, bookkeeping, shorthand, physics, photography and so on. 
Currently (2010) there are more than 63,000 enrolled students, including 21,000 international students representing more than 100 countries. The heritage of starting as a union supported college for working men has seen the university orientate itself in such a way where curriculum and applied research are heavily influenced by current industrial practice.

The clear industrial orientation and interest in applied rather than pure research provides an interesting beginning and backdrop to the history of the creation of information systems programs. The story of curriculum development presented in this narrative involves academics who were recruited to the University because of their industrial experience rather than because of their traditional academic experiences such as research, publications and grant success.

\subsection{Method}

This history was constructed from original documents such as brochures, Faculty of Business handbooks, course guides and internal university documents. Face to face interviews were also conducted with Cliff Forester, Audra Lukaitis and Stasys (Stas) Lukaitis. Cliff Forester was employed by the University after leaving Caulfield Institute in 1965 to help teach in the courses set up by Brian O'Donoghue as part of the then accounting degree. Audra Lukaitis and Stasys Lukaitis worked for different parts of the University, and were brought together by the formation of the new department of business information systems, on the centenary of RMIT's opening, 1987. This means that they were able to observe the evolution of existing courses into degree programs in information systems first hand.

\subsection{Setting the Scene - Before the Department}

RMIT was considered to be a college of advanced education (CAE) (the same mission as a polytechnic) headed by director Brian W. Smith and associate director David Beanland who subsequently became the vice Chancellor when University status is achieved in 1992 along with the amalgamation with Philip Institute of Technology (PIT).

The history of computing at RMIT commences in 1962 with the lease of an Elliot 803 computer [2]. In 1986 the "Faculty of Business" (subsequently the Business Portfolio and now College of Business) was composed of the Department of accountancy, the Department of administrative studies and the Department of applied economics. In the first instance the Department of accountancy employed some people from industry to deal with the problem of students, particularly postgraduate students, wanting to be able to manage, oversight, implement or participate in the introduction of data processing equipment and systems into their organisations.

Eventually there were enough people to create a data processing group and for a leader of that group to the employed. The first leader was Cliff Forester who became so disenchanted with administrative tasks that he applied for leave to undertake a Masters in computing at the University of Texas. His replacement, Brian O'Donaghue, took the data processing group, now considerably enlarged because of the demand for courses, into the newly created Department of administrative studies. 
The group provided significant service teaching throughout the faculty of business as well as offering streams into some degrees. Eventually the Department of administrative studies graduate diploma degrees, starting with first computing program: the Graduate Diploma in commercial data processing. This timeline compares with the creation of the Department of Computer Science in 1981 [2].

\subsection{7 - The Department Is Born}

In 1987 the faculty of business saw the demand for information systems courses to be too large for a group within the administrative studies department. The Department of business information systems was created by Tony Adams (who replaced George Sutherland in 1984). Tony Adams had previously headed up a Computer Science group at RMIT, and before that had come from industry where he was the Data Processing Manager for Monash University. By the end of 1984 the Data Processing Group consisted of Tony Adams (Principal Lecturer), Neville Stern and Nigel Thomas (Senior Lecturers), and lecturers Cliff Forrester, Hugh Ballantyne, Philip Crutch and Stas Lukaitis to lead the new department [2].

\subsection{8 - An Undergraduate Degree Is Created}

In Australia university places are created by the federal government and partially funded by them. This funding arrangement was especially important for the formation of undergraduate degrees at that time. A new degree could only be created by taking student places away from other courses. RMIT had very successfully run secretarial business studies degrees and graduate diplomas in the 1960s and 1970s and had an outstanding reputation in this area. In the late 1970s the university hierarchy attempted to close the degrees. RMIT had underestimated the "fight back" response of the secretarial studies group who galvanised a large group of alumni, many of whom worked for powerful people in powerful places, including leading business leaders, politicians, and members of Parliament. There was a large "penultimate" city protest/demonstration with news coverage.

The secretarial group consisted of a small number of older (not too far off from retirement) women who had given good service to the Tech (as RMIT was fondly referred to), students and the community. Their educational standards were rigorous and their group was run along "traditional" lines, from another era. There was a strong hierarchy, a very strong commitment to "standards" from which the group did not swerve, there were many students who could never graduate as they could not meet specified required minimum skill standards (which were actually quite "high" by today's standards). In their way they kept up with technology, however were finally stumped by the introduction of the PC. The Tech had to "back down" from the total shutdown of the secretarial group, reviewing their position regarding redundancy.

The secretarial staff mostly had accounting qualifications, two staff members had extensive industry experience but no university qualifications. One particular staff member was also very active in the Victorian Institute of Management, and other business organisations. She also had a large network of important industry contacts that were beneficial to courses, subjects, staff, students and the Tech all round. As a result the old secretarial degree was rebadged as the Bachelor of Business (Office Systems). 
The New school, the Department of Computing (later renamed the Department of Business Information Systems) and undergraduate degree and postgraduate diplomas (a one year full-time or two-year part-time for graduates with a three-year university (or equivalent) degree were built on the funding allocated to the secretarial undergraduate four year degree (including the full-time year of work in industry). .

At that time there was no data processing undergraduate degree. So the school was built on the secretarial studies government funding. The funding was split 50/50 between two streams: office systems and business information systems (each stream consisting of 8 full semester units).

\subsection{New School Built on Large Compulsory Core Subject Enrolment}

Equally important, the school was also built on the large compulsory enrolment of all Faculty of Business students into the computing foundation subject "Computer Applications in Business". At that time over 1,300 students were enrolled in this subject. The whole school taught into this subject, including the Head of School and the Principal Lecturer both on campus and overseas, and every staff member contributed content, direction and teaching, including lectures and laboratory sessions. It was also at this time that the Faculty of Business started to experience a leap in Faculty of Business enrolments. Demand was burgeoning across all business programs.

\subsection{Computer Applications in Business Subject - Importance}

This subject (course) was always considered very important to the school, as it was the portal to other information systems and business computing subjects offered by the school, also it was an important source of university funding, It was a core subject of all Faculty of Business degrees. Incidentally the content and style of the subject was built on industry consultancies delivered by RMIT's Australian Microcomputers Industry Clearing House (AMIC) - a consulting arm of the University staffed by department academics and other computer specialists.

Although generally the software and other concepts have changed with developments and projected developments in computing in business, the framework is essentially the same as it was 24 years ago. Like the London underground map, the introductory computing subject map put together by the data processing and office systems groups has stood the test of time.

\subsection{8 - The First Bachelor of Business (Business Information Systems) Degree and Growth in Postgraduate Diploma Enrolments}

By 1988 the new Bachelor of Business (Business Information Systems) consisted of two major streams: Business Information Systems and Office Systems. The new program extended over four years (of which there was a one year work placement component).

Each stream also offered a one year full-time, or two-year part-time, graduate diploma (a postgraduate qualification) consisting of eight subjects. The jobs the office systems postgraduate course targeted for their graduates were Systems Training Officer, Market Planning Manager, Personnel Officer, Information Manager, Personnel Officer, Projects Coordinator, Change Management Consultant, Office Technology 
Consultant, Data Base Systems Officer, International Marketing Specialist and such like. Business Information Systems targeted jobs such as Systems Analyst, Database Programmer/Analyst/Administrator and information technology consultant and advisor.

The Postgraduate Diploma in Secretarial Studies continued (with large numbers of students still applying). The Postgraduate Diploma in Commercial Data Processing also still continued (with large numbers of students applying and growing). 1988 also saw the launch of the first Bachelor of Business (Marketing) in the Faculty of Business. In addition, application had been made to the appropriate authorities to change the names of several courses currently offered by the faculty. It is pertinent to note that at that time all programs were fully funded by the Government and places were offered to students on a competitive basis, students did not pay fees.

\subsection{Consulting and Industry Engagement}

The department and its academic staff had arisen from demands of industry for job specific training. This was (and is) reflected in working conditions and priorities. Until recently $\mathrm{PhD}$ qualifications were seen as irrelevant as the role of the college of advanced education was "more applied and less research-oriented than universities" [3:121]. The Martin Report [4] tabled in 1964-65 recommended the creation of colleges of advanced education rather than the expansion of universities to cope with the demand for more universities places. The mission of the College of Advanced Education (CAE) was therefore very different from that of a university.

Rather than research, RMIT, CAE academics were required to teach or consult into industry and maintain close links with industry. In her interview Audra Lukaitis describes this priority

"It was a very heavy load to work in industry as a consultant and then work full-time as an academic. Nevertheless this experience was to prove absolutely invaluable to me and has informed my whole approach to computing education. To industry I was able to bring fresh ideas, concepts and theories garnered from research in my fields, and from industry I was able to bring back real world case studies that informed all assignments, approaches and curriculum content. I was able to see firsthand what really went on in industry as a participant and bring it back to the classroom."

In an interview, Stas Lukaitis remarks

Perhaps it might be of interest to note that AMIC - Australian Microcomputer Industry Clearinghouse - was created by an enterprising Tony Adams and others in response to the "sudden" arrival of microcomputers onto the scene. The demand for short courses and consultancies on the use and deployment of micros, their software e.g. - Visicalc, Lotus, MultiMate, WordStar, Dbase was huge and AMIC blossomed. Several BIS staff were recruited from the ranks of the consultants who worked at AMIC (e.g. Peter Viola who was a Manager at AMIC for many years).

Academics who worked at AMIC were actually paid at standard industry consulting rates. It was this that created a great deal of angst from the Chancellery who demanded that academics stop being paid so much. That was the start of the demise of AMIC, the birth of the MDC and the end of academic input into University education engagement. 


\subsection{International Demand}

Right from the formation of the Department of Business Information Systems (now School of Business Information Technology and Logistics) the founding Head, Tony Adams along with others in the Faculty of Business began to pioneer and establish international education initiatives onshore and offshore, namely in Malaysia, Singapore and Hong Kong, particularly Barry Cooper who setup the original Malaysian operation at Taylors College.

Staff were now required to teach overseas (in addition to consulting in industry), which certainly added another challenge, but without a doubt yet another valuable dimension. Groups of students from around the world appeared in classrooms, this brought many new challenges for which many staff were unprepared - academic standards, assumptions, English language proficiency, writing and comprehension, extremes in diversity, cultural differences - all had to be dealt with. The international student market was grown very aggressively and successfully by Barry Cooper from Accountancy, Colin Bent and Tony Adams (onshore and offshore). They were initially the ones who had the vision to expand RMIT's activities globally, they were the pathfinders. Once again, teaching overseas was considered to be "above load", so academics were paid separately for overseas teaching while still putting in full time back home, nevertheless all academics were required to teach overseas.

\section{Life and Death of Office Systems}

New Office Systems subjects: Principal Lecturers were responsible for the main groupings of staff who delivered subject (courses, subjects = programs, courses). Department of Administrative Studies: Tony Adams, James Hearne, James Hurley.

Table 1. 1986 Undergraduate Programs

\begin{tabular}{|c|c|c|c|}
\hline \multicolumn{3}{|c|}{1986 - Undergraduate Programs } & $\begin{array}{l}\text { Special } \\
\text { Comment }\end{array}$ \\
\hline $\begin{array}{l}\text { Course Name } \\
\text { Bachelor of Business in } \\
\text { the fields of: }\end{array}$ & Department & $\begin{array}{l}\text { Program } \\
\text { Length }\end{array}$ & $\begin{array}{l}\text { One Year Industry } \\
\text { Experience Supervised } \\
\text { professional practice }\end{array}$ \\
\hline Accountancy & Accountancy & 4 & $\sqrt{ }$ \\
\hline Business Administration & $\begin{array}{l}\text { Administrative } \\
\text { Studies }\end{array}$ & 4 & $\sqrt{ }$ \\
\hline Local Government & $\begin{array}{l}\text { Administrative } \\
\text { Studies }\end{array}$ & 4 & $\sqrt{ }$ \\
\hline Property & Applied Economics & 4 & $\sqrt{ }$ \\
\hline Public Administration & $\begin{array}{l}\text { Administrative } \\
\text { Studies }\end{array}$ & 4 & $\sqrt{ }$ \\
\hline Transport & Applied Economics & 4 & $\sqrt{ }$ \\
\hline Secretarial Studies* & $\begin{array}{l}\text { Administrative } \\
\text { Studies }\end{array}$ & 4 & $\begin{array}{l}\text { No new } \\
\text { students } \\
\text { may enrol } \\
\text { as this } \\
\text { course is } \\
\text { undergoing } \\
\text { review }\end{array}$ \\
\hline
\end{tabular}


* Students who were still currently undertaking this course would complete their studies in accordance with the 1984 Advanced College Handbook.

Table 2. 1986 Postgraduate Programs

\begin{tabular}{|ll|}
\hline \multicolumn{2}{|c|}{1986 - Postgraduate Programs } \\
\hline $\begin{array}{l}\text { Graduate Diploma (Prerequisite - 3-year undergraduate } \\
\text { degree) }\end{array}$ & Department \\
\hline Commercial Data Processing (Grad. Dip. Comm. Data Proc.) & Administrative Studies \\
\hline Finance (Grad. Dip. Fin.) & Accountancy \\
\hline Internal Auditing (Grad. Dip. Int. Aud.) & Accountancy \\
\hline Management (Grad. Dip. Mgmt) & Administrative Studies \\
\hline Organizational Development (Grad. Dip. Org. Dev.) & Administrative Studies \\
\hline Real Estate Development and Investment (Grad. Dip. R.E. \& Inv.) & Applied Economics \\
\hline Secretarial Studies (Grad. Dip. Sec. Stud.) & Administrative Studies \\
\hline Taxation (Grad. Dip. Tax.) & Accountancy \\
\hline Accounting and Auditing & Accountancy \\
\hline Health Services & Administrative Studies \\
\hline
\end{tabular}

Table 3. 1987 Postgraduate Programs

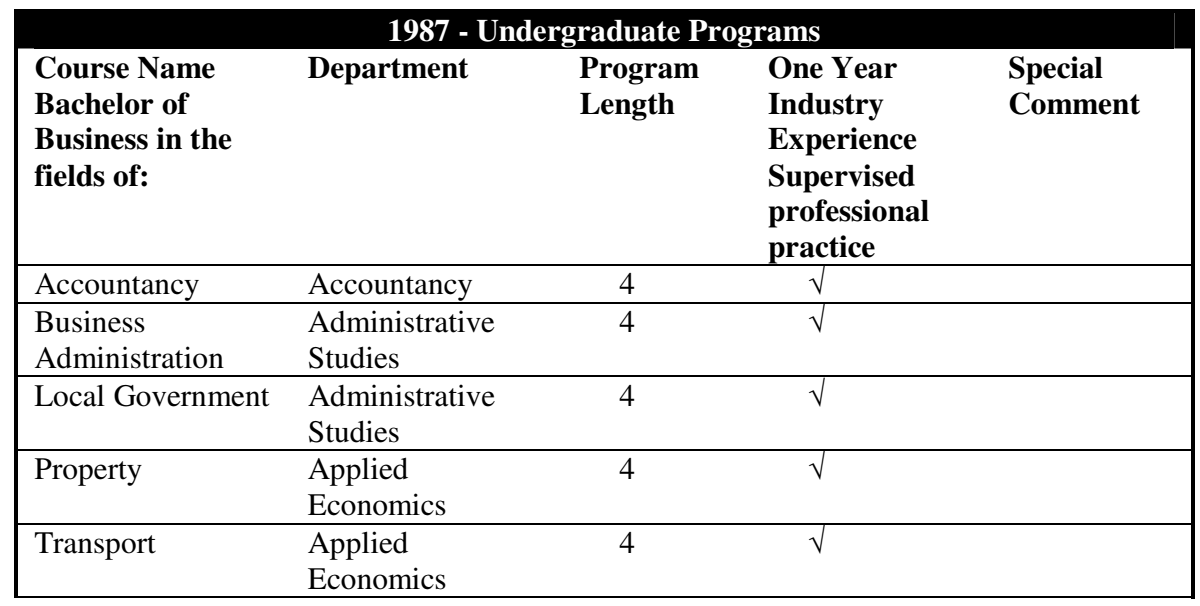

Dean Noel Anthony appointed Foundation Dean of the Faculty of Business in 1977, commencing as a Lecturer in Accountancy in 1963 after many years service with the State Bank of Victoria. Appointed Head School of Business Studies in 1976, was also Acting Associated Director, Advanced College. Noel Anthony was responsible for the new extensive computer facilities within the Faculty; he was actually the one who encouraged the Faculty of Business Computing Group to acquire and deploy the new microcomputers and funded the setup of the first PC labs in Business. Noel Anthony Retired in 1986, with the new Dean Dr. J. Milton-Smith appointed 1986, commencing in 1987. 
Department of Administration staff (relevant to future new school): Tony Adams, Hugh Ballantyne, Helen Carthew, Philip Crutch, Cliff Forrester, Eileen Gueho, James Hearne, Stas Lukaitis, Fiona Petersen, Margaret Petherick, Neville Stern, Nigel Thomas, Audra Lukaitis.

\section{7 - Centenary Year}

By 1987 the undergraduate degrees in Public Administration and Secretarial Studies were gone.

In postgraduate programs 2 were discontinued and 3 were renewed, rebated, or new.

1992 was the declaration of the Act establishing RMIT as a university and also the amalgamation of Philip Institute where the department acquired a new head Ken Millar and number of new staff.

$\begin{array}{ll}\text { 1984-1990 } & \text { Tony Adams Head } \\ 1990-1993 & \text { Neville Stern Acting Head) } \\ 1993-2001 & \text { Ken Millar (Head) } \\ 2002-2002 & \text { Tom Yardley (Acting Head) } \\ 2002-2003 & \text { Kevin Adams (Acting Head) } \\ 2003-2005 & \text { Caroline Dowling (Head) } \\ 2005-2005 & \text { Barry McIntyre (Acting Head) } \\ 2006- & \text { Brian Corbitt (Head) }\end{array}$

Remaining PIT people: Bill Davey, Elspeth MacKay, Lisa Keay

Table 4. 1986 Postgraduate Programs

\begin{tabular}{|lll|}
\hline \multicolumn{3}{|c|}{ 1987 - Postgraduate Programs } \\
$\begin{array}{l}\text { Course Name } \\
\text { Graduate Diploma (Prerequisite - 3-year } \\
\text { undergraduate degree) }\end{array}$ & Department & Comments \\
\hline $\begin{array}{l}\text { Transport and Distribution (Grad Dip Transport \& } \\
\text { Distribution) }\end{array}$ & Applied Economics & New \\
\hline $\begin{array}{l}\text { Commercial Data Processing (Grad. Dip. Comm. } \\
\text { Data Proc.) }\end{array}$ & Administrative Studies & \\
\hline Finance (Grad. Dip. Fin.) & Accountancy & \\
\hline Internal Auditing (Grad. Dip. Int. Aud.) & Accountancy & Discontinued \\
\hline Management (Grad. Dip. Mgmt) & Administrative Studies & \\
\hline Organisational Development (Grad. Dip. Org. Dev) & Administrative Studies & \\
\hline $\begin{array}{l}\text { Real Estate Development and Investment (Grad. } \\
\text { Dip. R. E. \& Inv) }\end{array}$ & Applied Economics & Discontinued \\
\hline Property (Grad. Dip. Prop.) & Applied Economics & New \\
\hline Secretarial Studies (Grad. Dip. Sec. Stud.) & Administrative Studies & \\
\hline Taxation (Grad. Dip. Tax.) & Accountancy & \\
\hline Accounting and Auditing & Accountancy & \\
\hline Health Services Management (Grad. Dip. HSM) & Administrative Studies & New \\
\hline
\end{tabular}




\section{Conclusion}

This historical record in this case of RMIT shows a number of very interesting outcomes.

The demise of secretarial studies and the degree programs that emerged with the creation of the information systems department seem illogical. Managers continue to have executive assistants and support staff who need to have particular skills in using technology and an understanding of information systems. The argument used against programs for these types of people seems to have been based upon a belief that secretarial studies consisted of training in technology that had been completely replaced by the computer. This argument concentrates on the replacement of the typewriter and shorthand with the word processor and dictaphones.

Another outcome may be reflected in the nature of information systems curriculum. At RMIT computer-based courses took two paths right from the beginning. Computer science was developed from the machine, its design, and programs that could run on it. Computer science was based in the disciplines of mathematics and applied physics and, as such, could be seen as valid integration of those two areas. The Computer Science department arose from the ashes of the Department of Mathematics and Computer Science, originally just Mathematics. It's of interest that most Computer Science people originated from maths and science where it was based. Much of the curriculum was scientific and mathematical with lip service (and contempt) paid to business and "commercial data processing" which was seen as particularly unsexy. CS degrees in the 1970's had compiler design, the solutions of differential equations, operations research, calculus, artificial intelligence and a peculiar form of software engineering. Your comments about IS arising from business demand is such a compelling factor that it has become lost.

On the other hand information systems arose from the demand from organizations to provide education and training for staff required to implement new technologies. In the late 1960s and early 1970s there was a plethora of courses aimed at producing workers in business capable of playing a part in the data processing of the business. The early programs offered by the data processing group and in the information systems department were heavily skewed towards postgraduate education. Vast numbers of students enrolled in postgraduate programs part-time so as to gain the computing skills and education needed in their new jobs.

It is no coincidence that the accounting department was an early sponsor of these courses and the creation of the data processing group. The Accounting Department would be the first to understand the changes happening in business due to introduction of computers in data processing.

When the first head of the information systems department came from computer science he may have been tempted to introduce some computer science rigor into the courses. His employment practices clearly indicated that he understood the difference between computer science and information systems. He hired senior people from IBM, HP and other businesses who would understand the needs of the graduates of these courses. This meant that the courses developed by the information systems department were heavily biased towards current practice in industry. The programming languages Cobol rather than FORTRAN. Systems subjects were prominent in many subject names used the words data processing. 
This paper recounts the history of the single university's information systems degrees. It would be interesting to look at the history of other information systems programs to see if similar backgrounds have produced an environment similar to that of the current information systems programs at RMIT.

\section{References}

1. Tatnall, A., Davey, B.: Streams in the History of Computer Education in Australia. In: Impagliazzo, J., Lee, J.A.N. (eds.) History of Computing in Education, pp. 83-90. Kluwer Academic Publishers/IFIP, Assinippi Park (2004)

2. Tatnall, A.: Curriculum Cycles in the History of Information Systems in Australia. Heidelberg Press, Melbourne (2006)

3. Karmel, P.: The Role of Central Government in Higher Education. Higher Education Quarterly 42(2), 119-133 (Spring 1988)

4. Martin, Sir L. (Committee Chair): Report of the Committee on the Future of Tertiary Education in Australia the Martin Report, 3 vols. Australian Universities Commission, AGPS, Canberra (1964-1965) 